Nig. J. Biotech. Vol. 37(1): 55-62 (June 2020)

ISSN: 01891731

Available online at

http://www.ajol.info/index.php/njb/index

and www.biotechsocietynigeria.org

DOI: https://dx.doi.org/10.4314/njb.v37i1.6

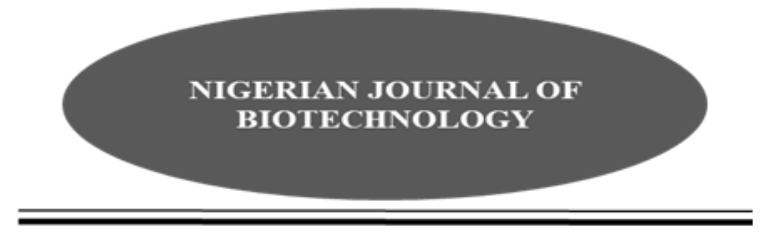

\title{
Mutagenic effects of sodium azide on the survival and morphological characters of tomato varieties
}

\author{
*Adeosun, C. A, Elem, K. A, and Eze, C. D. \\ Department of Plant Science and Biotechnology, University of Nigeria, Nsukka.
}

\begin{abstract}
Sodium Azide (SA)-induced mutagenic variability was studied on four tomato varieties namely Roma vf, Roma savannah, Tropimech and Tima. The SA concentrations used were $0.1 \%, 0.3 \%$, $0.5 \%$ and $0.7 \%$, with $0.0 \%$ as control to determine the percentage emergence and growth parameters of the tomato varieties. The plant seeds were pretreated with the various concentrations of the mutagen before planting. The seedlings were raised in the nursery and transplanted after 30 days of planting into the field in polythene bags filled with $70 \mathrm{~g}$ of a mixture of soil and farm yard manure. The experiment was carried out in randomised complete block design with three replicates. Increase in SA concentration caused a remarkable decrease in the percentage emergence and all other growth parameters evaluated. The effect of the interaction between variety and SA concentration revealed that the interaction was not significantly different from the control at $\mathrm{P} \leq 0.05$ on the number of leaves, number of branches and leaf length, but the difference was significant for plant height. Formation of two stems was observed at $0.3 \%$ Sodium Azide for Roma vf. variety. The $0.1 \%$ and $0.3 \%$ concentrations of Sodium Azide seem to be promising treatments under the experimental conditions and thus could be used to induce variations for tomato crop improvement. Tima and Roma savannah performed better and were resistant to the mutagen than other varieties, hence they can be recommended as good varieties for further breeding purposes; also Sodium Azide could be a good mutagen for the improvement of tomato plants.
\end{abstract}

Keywords: Tomato, growth characters, mutagenic, Sodium Azide, morphological variability.

*Corresponding author: chidiebere.adeosun@unn.edu.ng

\section{Introduction}

Plants are source of life for animals, as they constitute the primary producers of the ecosystem (Ilbas, et al., 2002). According to Krishma (2007), they are regarded as a source to three basic needs of man namely clothing, shelter and food. Humans obtain $85 \%$ of their calories from 20 plant species and $60 \%$ from just three grasses (De- Lannoy, 2001). The Federal Agricultural Organization yearbook (FAO, 2010) recorded that tomato is the $11^{\text {th }}$ most cultivated plant used as food. Aminu et al, (2017) and
Dhaliwal et al, (2002) affirmed that tomatoes as a cultivated crop is of high importance in some countries, while in other parts of the world it has witnessed a lot of negligence. Tomato has medicinal values which include its use for blood purification and cure for digestive ailments (Kaushik et al., 2011). Vitamins and antioxidants in tomatoes are essential for a healthy body; Lycopene and bioflavonoid which are in close relation with beta carotene are good antioxidants found in tomatoes and they express the natural cancer-fighting properties (De- Lannoy, 2001). 
Tomato medicinal properties were approved in continental Europe in the $16^{\text {th }}$ century, (Paven et al., 2009). Tomatoes consumption reduces cardiovascular disease and also helps in high blood pressure reduction, a major risk factor for coronary heart disease and stroke to relieve bloodshot eyes.

One of the serious challenges facing the global population today is the problem of food insufficiency and low quality standard. Tomato is one of the food crops with the potential to provide vitamins, calcium, protein and agro-based raw materials for the ever increasing global population (Bodunde, 2005; Kaushik et al., 2011). Adamu et al, (2004) reported the utilization of tomato as food and its other economic purposes. The value and utilization of tomato as a crop for both nutritional and industrial purposes primarily depends upon the quality of its composition. It is however disheartening that despite the significance of tomato to the world (in terms of food and health status of modern man), proper attention in terms of its improvement is lacking (Dhaliwal et al., 2017). A lot of efforts have been made to produce new cultivars with improved nutritional and physiochemical composition by manipulating economic crops. The discovery of Mutation breeding involving the creation and management of variability at the genetic level fostered efforts in development of improved cultivars (Adamu et al., 2004). The concept has gained prominence in recent years and has been used to produce a good number of desired cultivars from different crops by creating genetic variations which is an important step in successful plant breeding programmes (Adamu et al., 2004). Until midcentury, germplasm resources were inadequate for significant crop improvement or advances in genetic research (Adamu et al., 2002). The possibility of applying mutation to improve tomatoes quality has been scarcely investigated; hence, this work aims at inducing variability on tomato varieties using Sodium Azide.

\section{Materials and Methods}

\section{Experimental location}

This experiment was carried out in the plant breeding field, Botanical garden, Department of
Plant Science and Biotechnology, University of Nigeria, Nsukka, Eastern Nigeria.

\section{Source of seed material}

Seeds of tomato varieties namely Roma VF, Roma savanna, Tima and Tropimech in sealed envelopes were procured from the Department of Crop Science, University of Nigeria, Nsukka.

Sodium Azide solution preparation and seed pretreatment

The concentrations of SA (Sodim Azide) used in this work were $0.1 \%, 0.3 \%, 0.5 \%, 0.7 \%$ and $0.0 \%$ (served as control).

The procedure used in obtaining these concentrations was derived from the report of Eze and Dambo (2015) by measuring out $0.1 \mathrm{~g}, 0.3 \mathrm{~g}$ $0.5 \mathrm{~g}, 0.7 \mathrm{~g}$, each of the salt and dissolve it in distilled water and the solution made up to 100 $\mathrm{ml}$, while $0.0 \%$ solution is made up of $100 \mathrm{ml}$ of distilled water.

Seed pre-treatment was also done according to the method used by Eze and Dambo (2015). 50 seeds each of the different tomato varieties were pre-soaked in distilled water for four hours. The seeds were later divided into five groups of 10 seeds per group. The first four groups were then allocated for treatment by soaking them in Sodium Azide solutions of $0.1 \%, 0.3 \%, 0.5 \%$ and $0.7 \% \mathrm{SA}$, respectively, for twelve hours while the fifth group was soaked in distilled water (control). Thereafter, they were washed in running water and dried for twelve hours.

\section{Experimental design}

The seedlings were transplanted 30 days after planting (DAP) in a randomized complete block design (RCBD) with three replicates. Planting the treated seed involves sowing the seed into five different polythene bags per variety to obtain the seedlings; the polythene bags were filled with $750 \mathrm{~g}$ of a mixture of soil and farm yard manure with two punch holes to enhance drainage.

\section{Data collection}

The parameters measured were percentage emergence, plant height, number of leaves, leaf length, stem girth, and number of branching on 
a weekly basis after transplanting, while seedling root length was measured before transplanting.

\section{Statistical analysis}

The data collected was analysed using Statistical Analysis Software (SAS version 9.1) while means were separated using least significant difference (LSD) at $95 \%$ probability level.

\section{Results}

From the results obtained on percentage emergence of the tomato varieties treated with Sodium Azide (figure 1), There was a remarkable decrease in percentage emergence as the concentration of Sodium Azide increased with
$0.7 \%$ recording the lowest emergence percentage in each of the varieties. However, at $0.5 \%$, the responses of the tomato varieties to Sodium Azide are the same. Table 1 described the mean effect of variety on growth characters of the different varieties evaluated. Tima variety was significantly taller $(37.08 \pm 1.40 \mathrm{~cm})$ when compared with other varieties on plant height. In view of Table 2, it is apparent that Sodium Azide concentration had a mean effect on growth characters. The growth parameters for the control $(0.0 \%$ SA concentration) were significantly better than for those treated with different SA concentrations. The values of the parameters measured decrease with increasing concentration of Sodium Azide.

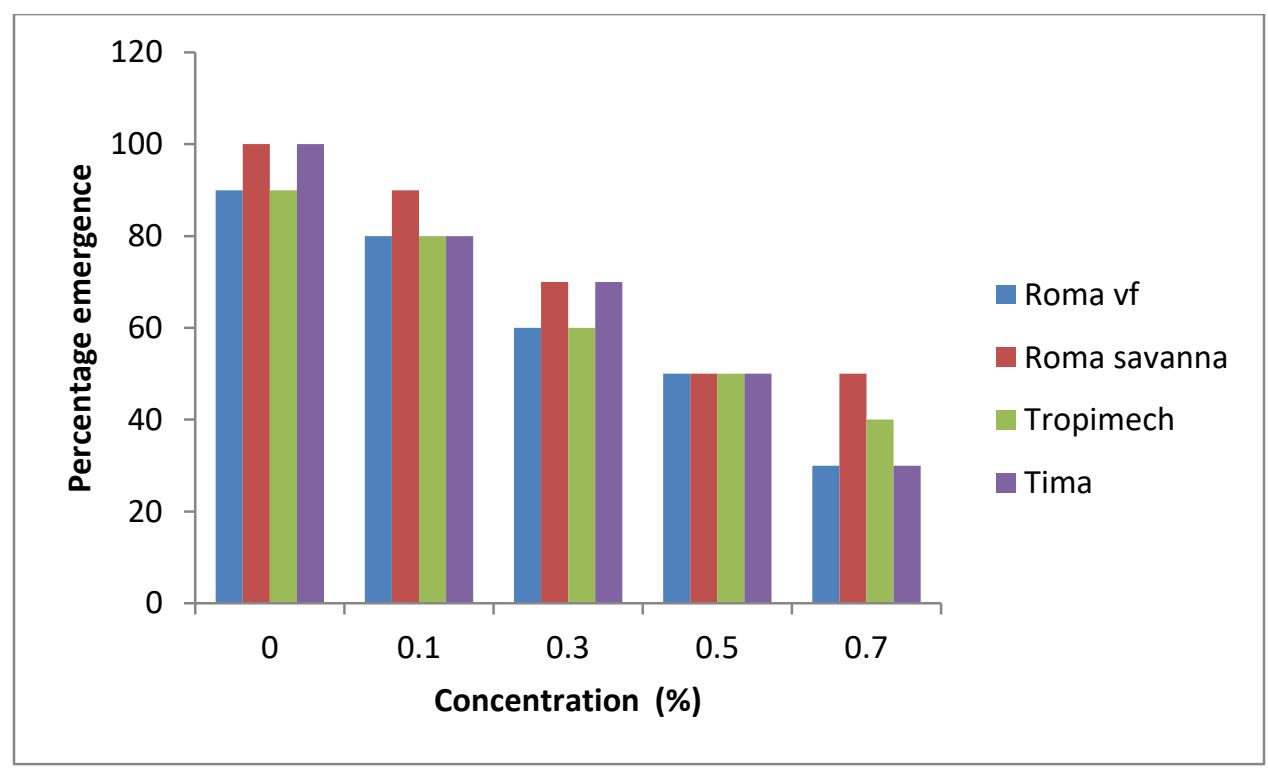

Figure 1: Effect of Sodium Azide (SA) concentration on percentage emergence of tomato varieties

Table 1: Mean effect of variety on growth characters

\begin{tabular}{l|rcccc}
\hline & \multicolumn{5}{|c}{ Growth characters } \\
\hline Variety & $\mathrm{PH}(\mathrm{cm})$ & $\mathrm{LL}(\mathrm{cm})$ & $\mathrm{SG}(\mathrm{cm})$ & $\mathrm{NB}$ & $\mathrm{NL}$ \\
\hline Roma vf & $30.33 \pm 3.10^{\mathrm{b}}$ & $3.61 \pm 0.36^{\mathrm{c}}$ & $2.14 \pm 0.20^{\mathrm{b}}$ & $4.64 \pm 0.47^{\mathrm{b}}$ & $50.78 \pm 4.7^{\mathrm{c}}$ \\
& & & & & \\
Roma Savana & $29.26 \pm 2.29^{\mathrm{b}}$ & $5.63 \pm 0.43^{\mathrm{b}}$ & $2.67 \pm 0.21^{\mathrm{a}}$ & $6.07 \pm 0.55^{\mathrm{a}}$ & $60.60 \pm 5.4^{\mathrm{a}}$ \\
Tropimech & $28.49 \pm 2.42^{\mathrm{b}}$ & $4.43 \pm 0.40^{\mathrm{c}}$ & $2.23 \pm 0.18^{\mathrm{b}}$ & $4.78 \pm 0.44^{\mathrm{b}}$ & $49.89 \pm 4.6^{\mathrm{d}}$ \\
\hline
\end{tabular}




\begin{tabular}{llllll}
\hline Tima & $37.08 \pm 1.40^{\mathrm{a}}$ & $8.40 \pm 0.59^{\mathrm{a}}$ & $2.20 \pm 0.12^{\mathrm{b}}$ & $4.33 \pm 0.47^{\mathrm{b}}$ & $68.76 \pm 4.6^{\mathrm{a}}$ \\
& $\mathbf{3 . 5 9}$ & $\mathbf{0 . 8 7}$ & $\mathbf{0 . 3 5}$ & $\mathbf{1 . 0 1}$ & $\mathbf{8 . 8 8}$
\end{tabular}

Means with the same letter within the same column are not significantly different. PH = plant height. $\mathrm{LL}=$ leaf length SG $=$ Stem girth $\mathrm{NB}=$ number of branches $\mathrm{NL}=$ number of leaves $\mathrm{LSD}=$ least significant difference.

Table 2: Mean effect of Sodium Azide concentration on growth characters

\begin{tabular}{llllll} 
Concentration & $\begin{array}{c}\text { Plant Height } \\
(\mathrm{cm})\end{array}$ & $\begin{array}{c}\text { Leaf Length } \\
(\mathrm{cm})\end{array}$ & $\begin{array}{c}\text { Stem Girth } \\
(\mathrm{cm})\end{array}$ & $\begin{array}{l}\text { Numbers } \\
\text { branches }\end{array}$ & $\begin{array}{l}\text { of } \\
\text { leaves }\end{array}$ \\
\hline 0.00 & $47.19 \pm 2.07^{\mathrm{a}}$ & $7.86 \pm 0.60^{\mathrm{a}}$ & $3.56 \pm 0.13^{\mathrm{a}}$ & $8.97 \pm 0.45^{\mathrm{a}}$ & $91.56 \pm 3.1^{\mathrm{a}}$ \\
0.10 & $37.76 \pm 1.62^{\mathrm{b}}$ & $6.41 \pm 0.47^{\mathrm{b}}$ & $2.81 \pm 0.10^{\mathrm{b}}$ & $6.78 \pm 0.54^{\mathrm{b}}$ & $69.39 \pm 3.9^{\mathrm{b}}$ \\
& & & & & \\
0.30 & $34.74 \pm 1.88^{\mathrm{b}}$ & $5.88 \pm 0.50^{\mathrm{bc}}$ & $2.33 \pm 0.15^{\mathrm{c}}$ & $5.81 \pm 0.50^{\mathrm{b}}$ & $59.53 \pm 4.9^{\mathrm{c}}$ \\
0.50 & $27.61 \pm 2.09^{\mathrm{b}}$ & $4.84 \pm 0.50^{\mathrm{c}}$ & $1.91 \pm 0.16^{\mathrm{d}}$ & $4.33 \pm 0.36^{\mathrm{c}}$ & $44.58 \pm 3.8^{\mathrm{d}}$ \\
0.70 & $13.90 \pm 2.41^{\mathrm{f}}$ & $2.58 \pm 0.49^{\mathrm{d}}$ & $0.93 \pm 0.16^{\mathrm{d}}$ & $2.22 \pm 0.38^{\mathrm{d}}$ & $22.47 \pm 4.1^{\mathrm{e}}$ \\
LSD & $\mathbf{4 . 0 1}$ & $\mathbf{0 . 9 7}$ & $\mathbf{0 . 3 9}$ & $\mathbf{1 . 1 3}$ & $\mathbf{9 . 9 3}$
\end{tabular}

Means with the same letter within the same column are not significantly different. LSD= least significant difference.

The synergistic effects of tomato varieties and Sodium Azide concentrations on the growth characters are presented in Table 3. The interactions between SA treatments and Tomato varieties revealed that Roma vf treated with $0.0 \%$ concentration of Sodium Azide has the highest mean and was significantly different from the other concentrations for plant height and stem girth, while there exists no significant difference $(P \leq 0.05)$ among the various concentrations for the number of branches and leaves.

The effect of variety and Sodium Azide concentrations on stem girth shows that Roma savanna has the highest mean on stem girth with $3.93 \pm 0.34 \mathrm{~cm}$ followed by $3.52 \pm 0.34 \mathrm{~cm}$ at $0.0 \%$ of Sodium Azide concentration of Roma vf and Roma savannah, respectively. The interactive effect of variety and Sodium Azide at $0.7 \%$ concentration on stem girth as presented in table 3 also depict that Roma savanna has the highest mean followed by Tima, Tropimech then Roma vf. There was no significant difference in the mean number of branches across the variety when treated with the different concentrations of Sodium Azide. However, the mean number of leaves decreases as the concentration of Sodium Azide increases, and at $0.3 \%$ concentration Roma savanna has the highest mean number of branches. No significant difference was recorded in the number of leaves among all the varieties treated at the various concentrations of Sodium Azide; Roma vf treated with $0.7 \%$ concentration of Sodium Azide had the lowest mean.

Table 4 showed that variety had a significant effect at $p \leq 0.001$ on the growth characters evaluated, except for stem girth which was significant at $P \leq 0.01$. The effect of $S A$ on the growth characters was also significant at $P \leq 0.001$. The synergy of variety and $S A$ treatment had no significant effect at $P \leq 0.05$ on the number of leaves. Second order interaction (Variety, concentration, and duration) showed significant $(p \leq 0.05)$ effect on the plant heights only, while it showed no significant effect on the other growth characters measured. 
Adeosun et al./ Nig. J. Biotech. Vol. 37 Num. 1 : 55-62 (June 2020)

Table 3: Synergistic effect of variety and Sodium Azide treatment on growth characters

\begin{tabular}{|c|c|c|c|c|c|c|}
\hline Variety & $\begin{array}{l}\text { concentration } \\
\%\end{array}$ & $\mathrm{PH}(\mathrm{cm})$ & $\mathrm{LL}(\mathrm{cm})$ & $\mathrm{SG}(\mathrm{cm})$ & NB & NL \\
\hline \multirow{5}{*}{ Roma vf } & 0.00 & $51.93 \pm 6.70^{a}$ & $4.90 \pm 0.59^{a}$ & $3.52 \pm 0.34^{a}$ & $8.11 \pm 0.73$ & $83.56 \pm 6.83$ \\
\hline & 0.10 & $38.60 \pm 3.99^{b}$ & $5.10 \pm 0.47^{a}$ & $2.74 \pm 0.23^{b}$ & $5.67 \pm 0.41$ & $62.22 \pm 3.57$ \\
\hline & 0.30 & $35.53 \pm 3.16^{b}$ & $4.31 \pm 0.72^{a}$ & $2.48 \pm 0.25^{b}$ & $5.78 \pm 0.78$ & $65.78 \pm 6.93$ \\
\hline & 0.50 & $25.59 \pm 2.29^{c}$ & $3.72 \pm 0.57^{a}$ & $1.94 \pm 0.09^{c}$ & $3.67 \pm 0.24$ & $42.33 \pm 2.37$ \\
\hline & 0.70 & $0.00 \pm 0.00^{d}$ & $0.00 \pm 0.00^{c}$ & $0.00 \pm 0.00^{d}$ & $0.00 \pm 0.00$ & $0.00 \pm 0.00$ \\
\hline \multirow{5}{*}{$\begin{array}{l}\text { Roma } \\
\text { savannah }\end{array}$} & 0.00 & $49.61 \pm 3.46^{e}$ & $7.78 \pm 0.22^{d}$ & $3.93 \pm 0.34^{\mathrm{e}}$ & $8.89 \pm 0.86$ & $92.00 \pm 7.83$ \\
\hline & 0.10 & $25.54 \pm 1.67^{g}$ & $6.01 \pm 0.37^{e}$ & $2.98 \pm 0.27^{f}$ & $6.78 \pm 1.05$ & $69.89 \pm 10.18$ \\
\hline & 0.30 & $25.98 \pm 4.949$ & $5.56 \pm 1.37^{\mathrm{de}}$ & $2.47 \pm 0.51^{\mathrm{fg}}$ & $6.78 \pm 1.58$ & $60.22 \pm 16.05$ \\
\hline & 0.50 & $24.70 \pm 4.78^{g}$ & $4.42 \pm 1.10^{f}$ & $2.29 \pm 0.49^{g}$ & $4.33 \pm 1.03$ & $41.56 \pm 9.52$ \\
\hline & 0.70 & $20.46 \pm 3.94^{g}$ & $4.37 \pm 0.91^{f}$ & $1.70 \pm 0.37^{h}$ & $3.56 \pm 0.73$ & $39.33 \pm 7.81$ \\
\hline \multirow{5}{*}{ Tropimech } & 0.00 & $43.43 \pm 2.16^{h}$ & $6.60 \pm 0.40^{g}$ & $3.40 \pm 0.16^{i}$ & $8.33 \pm 0.24$ & $85.67 \pm 2.23$ \\
\hline & 0.10 & $35.57 \pm 2.48^{i}$ & $4.80 \pm 0.25^{h}$ & $2.99 \pm 0.15^{i}$ & $5.89 \pm 0.63$ & $67.11 \pm 5.23$ \\
\hline & 0.30 & $31.34 \pm 3.35^{i}$ & $5.72 \pm 0.51^{g h}$ & $2.46 \pm 0.16^{i}$ & $4.78 \pm 0.57$ & $51.00 \pm 5.17$ \\
\hline & 0.50 & $25.64 \pm 5.63^{j}$ & $4.43 \pm 1.09^{h}$ & $1.78 \pm 0.40^{\mathrm{j}}$ & $3.89 \pm 0.84$ & $39.22 \pm 9.32$ \\
\hline & 0.70 & $6.47 \pm 3.24^{k}$ & $0.59 \pm 0.30^{i}$ & $0.53 \pm 0.27^{k}$ & $1.00 \pm 0.50$ & $6.44 \pm 3.25$ \\
\hline \multirow{5}{*}{ Tima } & 0.00 & $43.80 \pm 2.62^{1}$ & $12.16 \pm 1.45^{j}$ & $3.40 \pm 0.14^{\prime}$ & $10.56 \pm 1.32$ & $105.00 \pm 4.94$ \\
\hline & 0.10 & $39.34 \pm 2.40^{\mathrm{lm}}$ & $9.74 \pm 1.22^{k}$ & $2.54 \pm 0.16^{\mathrm{m}}$ & $8.78 \pm 1.63$ & $78.33 \pm 10.33$ \\
\hline & 0.30 & $39.08 \pm 2.05^{\mathrm{lm}}$ & $7.94 \pm 0.92^{1}$ & $1.92 \pm 0.17^{n}$ & $5.89 \pm 0.86$ & $61.11 \pm 9.13$ \\
\hline & 0.50 & $34.51 \pm 3.01^{\mathrm{lm}}$ & $6.80 \pm 1.00^{\prime}$ & $1.61 \pm 0.12^{n}$ & $5.44 \pm 0.41$ & $55.22 \pm 7.75$ \\
\hline & 0.70 & $28.69 \pm 3.45^{n}$ & $5.38 \pm 0.73^{m}$ & $1.50 \pm 0.14^{n}$ & $4.33 \pm 0.47$ & $44.11 \pm 6.04$ \\
\hline LSD & & 5.38 & 1.31 & 0.53 & NS & NS \\
\hline
\end{tabular}

Means with the same letter within the same column are not significantly different

$\mathrm{PH}=$ plant height. $\mathrm{LL}=$ =leaf length. $\mathrm{SG}=$ Stem girth. $\mathrm{NB}=$ number of branches. $\mathrm{NL}=$ number of leaves.

Table 4: Effects of variety, duration and concentration on growth characters

\begin{tabular}{|c|c|c|c|c|c|c|}
\hline $\begin{array}{c}\text { Source } \\
\text { of variation }\end{array}$ & Df & $\begin{array}{l}\mathrm{PH} \\
(\mathrm{cm})\end{array}$ & $\begin{array}{l}\mathrm{LL} \\
(\mathrm{cm})\end{array}$ & $\begin{array}{l}\text { SG } \\
(\mathrm{cm})\end{array}$ & NB & $\mathrm{NL}$ \\
\hline Variety & 3 & $696.88^{* * *}$ & $197.74^{* * *}$ & $2.71^{* *}$ & $56.47^{* * *}$ & $3591.22^{* * *}$ \\
\hline Concentration & 4 & $5253.63^{* * *}$ & $139.31^{* * *}$ & $34.97^{* * *}$ & $232.31^{* * *}$ & $24291.21^{* * *}$ \\
\hline Duration & 2 & $1186.56^{* * *}$ & $76.69^{* * *}$ & $2.83^{*}$ & $70.97^{* * *}$ & $7850.34^{* * *}$ \\
\hline \multicolumn{7}{|l|}{ Variety } \\
\hline $\begin{array}{c}\mathrm{x} \\
\text { Concentration }\end{array}$ & 12 & $459.46^{* * *}$ & $9.30^{*}$ & $1.38^{*}$ & $5.56^{*}$ & $753.54^{\mathrm{ns}}$ \\
\hline
\end{tabular}


Adeosun et al./ Nig. J. Biotech. Vol. 37 Num. 1 : 55-62 (June 2020)

\section{Variety}

XConcentration 24

$x$ Duration

$91.14^{*} \quad 1.50^{\mathrm{ns}} \quad 0.33^{\mathrm{ns}} \quad 2.45^{\mathrm{ns}} \quad 199.18^{\mathrm{ns}}$

${ }^{* * *}=$ highly significant at $p \leq 0.001 .{ }^{*}=$ Significant $(p \leq 0.05) . n s=$ non-significant $(p \leq 0.05) .{ }^{* *}=$ highly significant $(p \leq 0.01) P H=p l a n t$ height. $\quad \mathrm{LL}=$ leaf length. $\mathrm{SG}=$ Stem girth. $\mathrm{NB}=$ number of branches, $\mathrm{NL}=$ number of leaves.

Table 5 represents the mean effect of concentration on Sodium Azide variety. It revealed that between $0.00 \%$ and $0.70 \%$ as well as $0.10 \%$ and $0.70 \% \mathrm{SA}$, there exists a significant difference across the varieties; but between $0.50 \%$ and $0.70 \%$, there was no significant difference among the varieties except for the Tima variety.

Table 5: Mean effect of Sodium Azide concentration on variety

\begin{tabular}{lllll}
\hline Concentration & Roma vf & Roma savannah & Tropimech & Tima \\
\hline 0.00 & $6.57 \pm 0.19^{\mathrm{a}}$ & $7.23 \pm 0.29^{\mathrm{a}}$ & $4.23 \pm 0.23^{\mathrm{a}}$ & $8.60 \pm 0.25^{\mathrm{a}}$ \\
0.10 & $5.87 \pm 0.27^{\mathrm{a}}$ & $6.30 \pm 0.71^{\mathrm{b}}$ & $3.90 \pm 0.31^{\mathrm{ab}}$ & $6.17 \pm 0.71^{\mathrm{b}}$ \\
0.30 & $5.00 \pm 0.59^{\mathrm{c}}$ & $4.40 \pm 0.06^{\mathrm{c}}$ & $3.27 \pm 0.38^{\mathrm{b}}$ & $4.80 \pm 0.42^{\mathrm{c}}$ \\
0.50 & $3.80 \pm 0.29^{\mathrm{d}}$ & $3.10 \pm 0.15^{\mathrm{d}}$ & $2.30 \pm 0.06^{\mathrm{c}}$ & $3.23 \pm 0.57^{\mathrm{d}}$ \\
0.70 & $3.40 \pm 0.65^{\mathrm{d}}$ & $2.43 \pm 0.07^{\mathrm{d}}$ & $1.77 \pm 0.15^{\mathrm{c}}$ & $2.47 \pm 0.22^{\mathrm{e}}$ \\
\hline
\end{tabular}

$\mathrm{LSD}-0.74$. Means with the same letter within the same column are not significantly different.

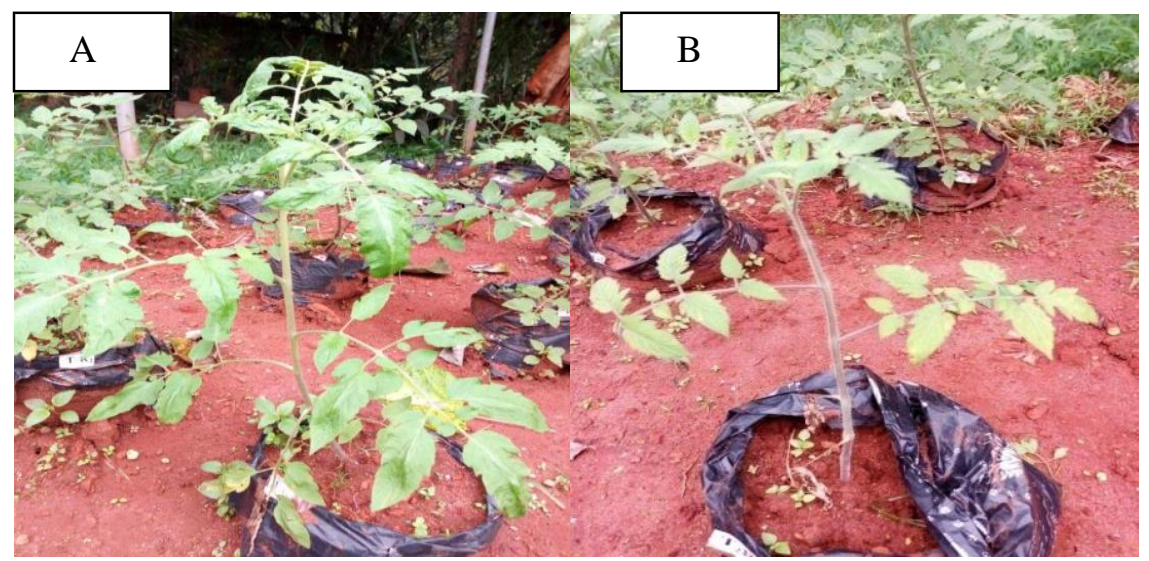

Plate 1: (A) Tropimech treated with $0.0 \%$ SA concentration showing many leaves

(B) Tropimech treated with $0.5 \%$ SA concentration showing few leaves 

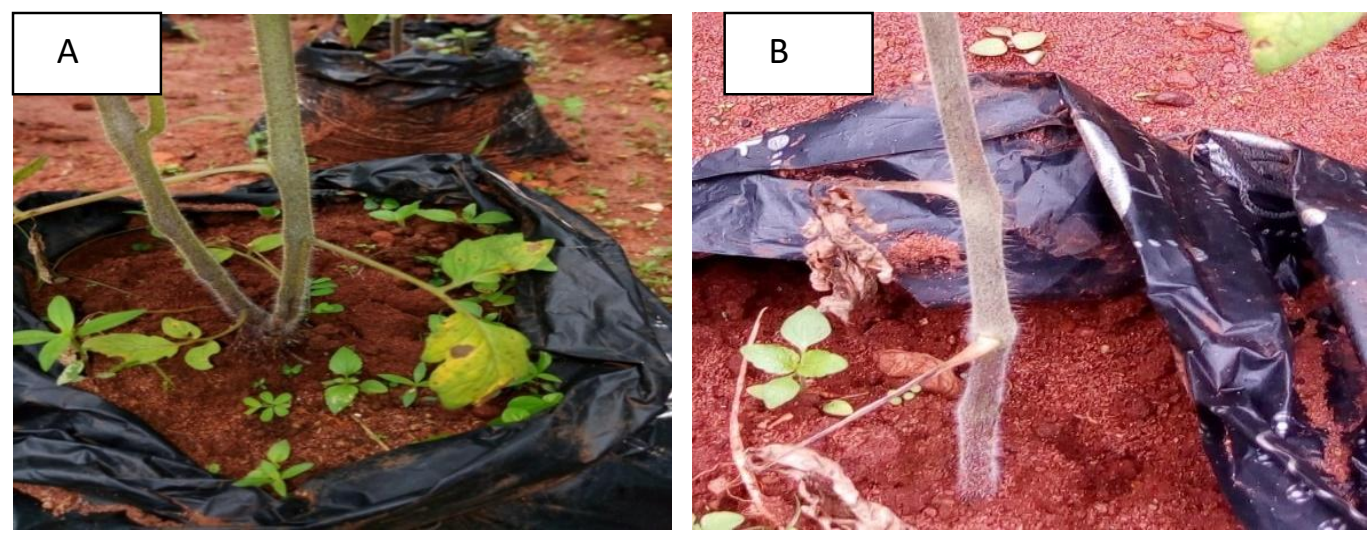

Plate 2: (A) Roma Vf treated with $0.3 \%$

SA concentration showing two stems

(B) Roma Vf treated with $0.0 \%$ SA concentration showing one stem

\section{Discussion}

The results obtained from this study showed that Sodium Azide can lead to a decrease in percentage emergence, reduced seedling root length, reduced plant height, and less number of leaves, branches and also decrease in stem girth as the treatment level increases. These agreed with the report of Aliyu and Adamu (2007) and Aminu et al. (2017). Similarly, Sheeba et al. (2005) reported the effect of gamma rays and EMS on Sesanum indicum L; the report showed a significant reduction in seed germination, seedling survival, Plant height and pollen fertility with an increase in dosage levels of both mutagens. Low yield was reported on mutant types of Okra (Abelmoschus esculentum) by Sasi et al. (2005).

From this study, Sodium Azide was found to be very effective in inducing mutations. The ranges observed in stem girth, numbers of leaves, number of branches, percentage emergence and plant height in this study were much wider as compared to the report of Aliyu and Adamu (2007) and the differences can be attributed to the variation induced by Sodium Azide.

Undoubtedly, it is expected that taller plants would have more branches and more number of leaves, which was observed in Tropimech, Tima and Roma savanna. However this was not the case in Roma vf variety which was obviously taller at $0.0 \%$ concentration of Sodium Azide than at $0.3 \%$, but reverse was the case in its numbers of leaves and branches. These differences in height, number of branches and leaves in Roma vf at these concentrations were probably due to formation of two stems which the plant had (plate $2 \mathrm{~A}$ ) and possibly is a response to mutagenic treatment when compared to the control. Therefore, variation could be due to the mutagenic effect of sodium azide as these two stems were not ideal in the control groups.

According to Munir et al. (2015), increase in concentration of Sodium Azide brings a corresponding decrease in plant growth. This was confirmed by the present study as an increase in the mutagen concentration brought about a decrease in plant height and number of leaves as observed in Tropimech. Lethality was observed one week after transplanting in Roma vf treated with $0.7 \%$ SA concentration, which supported the findings of Aliyu and Adamu (2007) who reported a lethal effect of Sodium Azide on T224 and T420 tomato varieties when treated with $4 \mathrm{mM}$ concentration of Sodium Azide.

\section{Conclusion}

Sodium Azide was able to induce morphological variability in the tomato varieties and therefore can be used in crop improvement of tomato plants. $0.1 \%$ and $0.3 \%$ concentrations of Sodium Azide had the best expression on the morphology of the different varieties and so can be seen as optimum concentrations for best quality in tomato and possibly other food crops. Tima and Roma savana maintained high percentage 
emergence despite the increase in the concentration of Sodium Azide making it a better variety for breeding and research purposes, as well as good variety for improvement. Further research can be done in areas like determining the molecular variability induced by Sodium Azide on these varieties, the mutagenic effect of Sodium Azide on the mitotic expression of their root tips and also the resistance to pest and diseases of the mutated varieties and their reaction to environmental stress in other to improve tomato production, enhance food security and avert the ecological implication of using pesticides to control plant pest.

\section{References}

Adamu, A. K. and Aliyu, H. (2007). Morphogical effects of Sodium azide on Tomato (Lycopersicon esculentum Mill). Sci. WId. J. 2 (4): 6-12.

Adamu, A. K., Clung, S. S. and Abubakar, S. (2004). Effects of ionizing radiation (gammarays) on tomato (Lycopersicon esculentum L.). Nig. J. Exp. and App. Biol. 5 (2): 185-193.

Adamu, A. K., Oluranju, P. E., Bate, J. A. and Ogunlade, O. T. (2002). Radio sensitivity and effective dose determination in groundnut (Arachis hypogaea L.) irradiated with gammarays. J. Agri. and Environ. 3 (1): 17-84.

Aminu , Y., Bala, B. U., Kabiru, H. U. and Musbalu, A. A.(2017). Induced - growth and yield response to seasonal variation by Sodium azide in tomato (Solanum lycopersicon). Bayero J. Pure and App. Sci. 10 (1): 226-230.

Bodunde, J. G. (2003). Seasonal variation effects on flower formation and fruit set in tomato (Lycopersicon esculentum Mill.). ASSET J. 7 (3): 69-77.

De Lannoy, G. (2001). Vegetables in remain, H.R. Crop Production in Tropical Africa, pp. 466-475.

Dhaliwal, M. S., kaur, A. and Singh, S. (2002). Genetic analysis and correlations involving populations derived from Solanum lycopersicon and S. pinpuellifollin crosses tomato. J. Gen. and PInt. Breed. 56: 345-352.

Eze J. J, and Dambo, A. (2015). Mutagenic effects of Sodium azide on the quality of maize seeds. $J$. Adv. Lab. Resch. in Biol. 6 (3): 76-82.
Food and Agricultural Organization (2010). FAO statistical year Book, Rome, Italy.

Ilbas, A. I., Eroglu, Y. and Eroglu, H. E. (2005). Effect of the application of different concentrations of Sodim azide for different times on the morphological and cytogenetic characteristics of Barley (Hordeum vulgare L.) seedling. Acta Botanica Sinica, 22 (47): 11011106.

Kaushik, S. K., Tomar, D. S. and Dixit A. K.. (2011). Genetics of fruit yield and its contributing characters in tomato (Solanum lycopersicom). J. Agri. Biotech. and Sust. Dev. 44 (3): 209 -213.

Krishma, U. (2007). Plant breeding as a tool for acquisition of new germplasm. Eucalytica, 119 (52): 28-34.

Munir, N., Safdar, I and Naz, S. (2015). Effect of induced mutation for varietal improvement in some local grapevine cultivars. J.Anil. and PInt. Sci. 25 (1): 234-242.

Sasi, A., Dhanavel, D. and Paradai, P. (2005). Effect of chemical mutagenesis on bhendi (Abelmoschus esculentus (L.) moench var. MDU1). Res. on Crps. 6(2) 253-256.

Sheeba, A., Abumalarmalhi, J., Babu, S. and Ibrahim, S. nM. (2005). Mutagenic effects of gamma rays and EMS in M1 generation in sesame. Res. on Crps. 6(2): 300-306. 